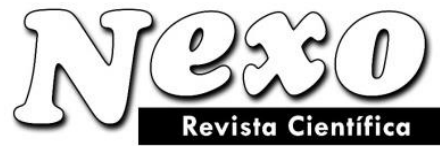

ISSN-E 1995-9516

Universidad Nacional de Ingeniería COPYRIGHT @ (UNI). TODOS LOS DERECHOS RESERVADOS http://revistas.uni.edu.ni/index.php/Nexo https://doi.org/10.5377/nexo.v34i01.11301

Vol. 34, No. 01, pp. 219-228/Marzo 2021

\title{
Public administration in the context of reflection of the modern innovative dig- ital level of economic development
}

\section{La administración pública en el contexto de la reflexión del nivel digital inno- vador moderno de desarrollo económico}

\author{
Georgy V. Ovcharenko ${ }^{1,{ }^{*}}$, Galina V. Petruk ${ }^{2}$, Natalia G. Larkina ${ }^{3}$, Alexander P. Yalanskiy ${ }^{4}$ \\ ${ }^{1}$ South-Russian Institute of Management -Branch of the Russian Presidential Academy of National Econ- \\ omy and Public Administration under the President of the Russian Federation \\ 2 Vladivostok State University of Economy and Service \\ ${ }^{3}$ Department of Marketing and Communication in Business, Southern Federal University \\ ${ }^{4}$ Department of Political Science and Ethnopolitics, South-Russian Institute of Management -Branch of \\ the Russian Presidential Academy of National Economy and Public Administration under the President of \\ the Russian Federation \\ menedjment@uriu.ranepa.ru
}

(recibido/received: 02-December-2020; aceptado/accepted: 01-February-2021)

\begin{abstract}
The article analyzes the state and society's interaction to achieve an innovative idea based on strategic thinking and culture, which determine justice in society, realize their behavior, and substantiate the importance of innovative digital technologies in a neo-information society determines a person as innovative. The research shows the necessity of innovative thinking among different-level managers able to create and manage innovative knowledge of personnel, creating innovative values. A practical vector of the transition of the economy to an innovation level is proposed.
\end{abstract}

Keywords: innovative idea, innovative strategy, innovative thinking, innovative knowledge, innovative values.

\section{RESUMEN}

El artículo analiza la interacción del Estado y la sociedad para lograr una idea innovadora basada en el pensamiento estratégico y la cultura, que determina la justicia en la sociedad, reconociendo su comportamiento, y fundamenta la importancia de las tecnologías digitales innovadoras en una sociedad de neoinformación. lo que determina a una persona como innovadora. La investigación muestra la necesidad de un pensamiento innovador entre los gerentes de diferentes niveles capaces de crear y gestionar el conocimiento innovador del personal, creando valores innovadores. Se propone un vector práctico de transición de la economía a un nivel de innovación. 
Palabras clave: idea innovadora, estrategia innovadora, pensamiento innovador, conocimiento innovador, valores innovadores.

\section{INTRODUCTION}

In terms of the state's development specifics, the creation of an effective organizational structure of power is determined by the communication interaction of all levels of government for making innovative management decisions based on a system of public institutions with a focus on protecting public interests. This means the state must serve the neo-society.

The relationship gives rise to opportunities for innovative ideas and projects, which determines innovative activity and the use of mechanisms for presentation of their interests through civil solidarity, subject to innovative information technologies under state control, through the instructions of the President of the Russian Federation V.V. Putin not followed by ministries.

Subject to the above, the authors note that the synergistic level of power is determined by the level of culture and strategic thinking ability and should be considered a factor of economic competitiveness.

A.N. Ovcharenko notes that strategic management in state policy activity is the process of developing and implementing a general course, determining the political, economic, and environmental conditions for its implementation (Ovcharenko, 2007), considering the need for political culture at all levels of government.

D. Snyder stated that "strategic culture... in turn is a broad manifestation of public opinion, expressed in a special form of strategic thinking (Jack, 1977), which is a defining element of strategic culture, which determines the mechanism of reflexive self-organization of the thinking process, considering the creative approach to implementation of innovative potential, contributing to new opportunities in strategic activities subject to the uncertain dynamics of situations.

Following modern etymology, the modern public consciousness has a need for managing leaders able to think strategically and assess the tactical situation for the implementation of an innovative breakthrough, based on the forecast of future development while bearing personal responsibility for justice in the neosociety, which is a category of ethics and is considered the virtue of man in all philosophical teachings.

Plato stated justice to be an opportunity to realize oneself by one's own means (Plato, 2015), as the basis of justice itself is trust, mutual respect, mutual understanding, because wealth and privileges are most often perceived as the main social injustice, as the main public value is justice (Berdiaev, 1990).

The authors note that Russian society, historically, has given preference to justice, which was treated as the basis of socio-political security (Ovcharenko et al., 2020).

\section{RESULTS AND DISCUSSION}

The President of the Russian Federation V.V. Putin noted in his message to the Federal Assembly that the main challenge of the state apparatus and the elite of Russia is the innovative management of the country in modern society, which forms the consciousness and behavior of such a social group as youth and students.

Theoretically, the development of the social sciences leads to a shift in understanding the factors influencing historical processes and the formation of consciousness in social groups. This is especially evident in the studies of V. Pareto, who noted that "... society is a system in a state of equilibrium", as the saturation of society with social changes is different due to the socio-historical diversity, which determines the im- 
plementation of the interests of society and the state, considering responsibility for the fate of the Motherland.

Practically, the integration process of economies (globalization) determines the mutual influence of social processes, the driving factor of which is innovative, information, and communication digital technologies that transform the structure of the economy while preserving the characteristics and traditions of the specifics of national cultures, which gives rise to a variety of socio-political relations in the world.

The authors, however, note that the well-being of the development of the new economy is predetermined by economic aspects, such as wages, the level of inflation, and unemployment, considering the state of prices for products, which are solved only under state management of all sectors of the economy on the basis of high-tech production when implementing innovative domestic technologies, considering the availability of new knowledge in the staff. According to the World Economic Forum, Russia ranks 60th in the level of technological development (Germany - 3rd place), and 4th in the volume of the shadow economy, amounting to 34 trillion. rub., which is equal to $39 \%$ of the country's GDP.

In the XXI century, communicative network technologies become a kind of working tool of an "innovative person", that is, constituted a new social morphology of society" (Semenov, 2013), which determines new opportunities for partnership between state institutions and civil society organizations in discussing socially significant problems, contributing to the social self-organization of citizens of the country. That is, there is a need for innovative forms of mutually beneficial confidential interaction between the neosociety and the state and the formation of levels of innovative and social culture of citizens.

Analysis of the logic of the above shows that a person must realize and evaluate his past and present on the basis of new thinking to understand the values of national history and culture.

P.I. Pestel noted that "the people have both the duty to obey the government and the right to require the government striving for public and private welfare and only command what truly leads to and is essential for achieving this goal" (Pestel, 1972), that is, the government defends his personal moral freedom, honor, and dignity.

N.A. Berdiaev stated that "... a Russian person could live a dignified Russian life, that is, following $n a$ tional values" (Berdiaev, 2010), which would ensure democracy and a social and legal state.

From a scientific point of view, the modern neo-information society is characterized by the inconsistency of the innovation sphere (the interaction of innovators, investors, and producers of goods), which is caused by the uncertainty of the conjuncture and the global economic crisis.

Based on the synergetic approach, Russia as a state is at a new level of innovative potential and at the same time a low level of technological production with prevailing technologies of the 3rd and 4th technological paradigms. This prompts the leaders of all levels of management to implement the concept of continuous innovative activity of all regions at on the basis of mutually beneficial and trusting scientific partnership of the state, science, education, manufacturers, and society to create an innovative breakthrough in the formation of a new economic model.

"We need to look for solutions that would help overcome the emerging one-sided technological dependence, ... it is necessary to build an effective mechanism for the renewal of the economy... with efficient agriculture, ... we need to carefully select priorities and preserve the scientific and production potential" (Putin, 2012).

In fact, the creation and management of scientific and technological innovations go through a crisis in all sectors of the economy (except for the military-industrial complex). Presidents V.V. Putin admits that 
"The innovative activity of the country's economy is very low. About five percent of the country's enterprises are actively applying new and newest achievements. Five percent only - while, for example, in Western Europe, this level reaches 80-87 percent".

The analysis of the foregoing and the assessment of the economic globalization show the increasing importance of innovative information digital technologies and intangible assets for the innovative development of the economy, which determines the creation of valence of investments in intellectual resources sources of foresight development in the context of dynamic correspondence between strategic priorities and innovative activity, determining the satisfaction of the changing needs of the neo-society and the welfare of people.

The authors note that A.I. Anchishkin stated in his studies that "All of the above actualizes the meaning and necessity based on innovative social technologies for the formation of a noospheric society, which provides at the innovative level the principles of individual freedom, its self-fulfillment based on free creativity and self-knowledge of one's freedom" (Anchishkin, 2003).

Theoretically, there is a need in innovative approach to the development and implementation of domestic innovative technologies that determine not only the innovative development of all sectors of the economy, but also the formation of an innovative policy of both regions and organizations at the global level, which will predetermine the innovative economic development.

"Strategy-2020" of the innovative development of the country notes that "the key task is to create conditions for the formation of competencies among managers for the implementation of innovative activities the intelligence of an innovative person as a subject of all innovative transformations" (Abdurakhmanova et al., 2020).

Practically, it becomes quite obvious that the implementation of such an approach is predetermined by the realization by different-level managers of the need for relevance and intention with the ability to create innovative knowledge in teams and flexibly and creatively manage it to create innovative product-services that meet the changing needs of the population.

Such a moment is reflected in the quote: "As the key features of the "tomorrow" system of public administration, the President of the Russian Federation indicated independence, bold and extraordinary solutions, support for initiatives in the regions and innovations based on the use of information technologies and the development of space infrastructure, noting that the implementation of these tasks in the regions is the federal "area of responsibility" (Putin, 2008). New scientific knowledge predetermine the innovative development of the economy as an innovative resource and the arch-influence of innovative digital technologies as key growth factors. This is noted in the concept of innovation policy of the Russian Federation, that "in the XXI century, the country's position in the geopolitical competition, along with education and public health, will determine the development of science and key production systems of the latest technological paradigm, the possibilities of the information environment, as well as the ability of the economic mechanism to generate high innovative activity" (Abdurakhmanova et al., 2020), in the context of the continuous improvement of new scientific knowledge and technologies, considering the rate of their renewal and the ability of different-level managers to manage these processes innovatively.

Subject to the above, the authors note that the pivotal state priorities of domestic policy are scientificdigital innovation and information renewal of production processes in all sectors of the economy, which determines not only world competitive leadership in innovative goods and services but also the creation of an innovative and investment climate for a new economy - an economy of innovative knowledge that determines the self-fulfillment of each individual in a group. 
The Russian scientist Iu.V. Iakovets notes that "the innovative dynamics of society is based on the new development of man, his spiritual world - neoscience, innovative culture, innovative education, embodied in the means of labor, transformed by the mind and labor of people" (Iakovets et al., 2000).

However, a premium should be put on the understanding and awareness by the state leaders of the need for innovative stimulation of the innovative activity of regions in the form of flexible legislation in innovative activity, effective methods for the implementation of innovative domestic technologies and the training of innovative managing leaders being able not only to develop and implement innovations in production in all sectors of the economy but also to manage new knowledge of personnel and technological redistribution (gaps), based on the concept of strategic planning based on strategic marketing information, that is, to implement the principle of learning and implementing faster than competitors, considering future positions.

O.S. Vikhanskii notes in his "The Firm's Secret" that "the ability to manage future development while creating new sensual values for people is determined by top managers' ability to reveal the hidden knowledge of employees for the growth of the company".

M. Lomonosov's reminder serves as a confirmation to the above that "there is a need for state guardianship over domestic industrial and commercial entrepreneurship, protective customs tariffs and even, in some cases, a ban on the import of goods that could be produced within the country".

The impact of external factors and the constant uncertainty of the conjuncture on the innovative activity of the organization determines the need to improve the methodology for managing process innovations within the organization, considering the strategic importance of innovative technologies, in the context of their adequacy to innovative changes in the formation of a new economy. In this regard, contemporary leaders of innovative organizations must be able to manage endless innovation to create innovative values in a team to make a person feel free at the workplace.

Nevertheless, we should admit that the assessment of the organization's innovative activity in the context of the implementation of the innovative strategy of technological development is determined on the basis of the analysis of innovative activity, which sets the vector of the leader's strategy in the presence and functioning of the innovative infrastructure, which allows both the creation of innovative knowledge and the introduction of its innovative technologies at all levels of management.

President V.V. Putin notes that "Russia needs a real technological revolution, a serious technological upgrade... and a technological re-equipment of our enterprises" (Putin, 2014).

It becomes obvious that unique knowledge about innovative opportunities determines the rationality of generating new knowledge for the implementation of the innovative technological strategy of a new innovative level of development in the formation of neo-economics.

The authors make a point that such a synergistic approach is confirmed by the statement of the President of the Russian Federation that "the only real alternative is the country's innovative development strategy, based on one of our main competitive advantages - the implementation of human potential. The pace of innovative development must be dramatically faster than we have today. This path is much more difficult. It is more ambitious and requires maximum effort from the state, business, and the whole society. But, in reality, we have no choice" (Putin, 2008).

Practically, the analysis of the theory and practice of innovative management shows that the success and implementation of the development and introduction of new innovative technologies are determined by the ability of managers to manage their time aspect, understanding "emotional taste" and usefulness. 
This approach determines the possibilities of combinations of internal factors of production for the organization's innovative development, that is, the achievement of an innovative goal - the creation and commercialization of innovations in the context of the cyclical nature of the algorithm of innovative processes.

Thus, the analysis of the innovative knowledge system of KZ Rostselmash LLC and the elements of its interaction with the help of computer-aided modeling predetermines the vision of practical methods of managing innovations and their uniqueness, which makes it possible to pursue a policy of innovative development - the annual production of a new model of the harvester, which causes constant innovativeness: of the organizations, namely:

- open-mindedness of personnel to innovations;

- updating of staff knowledge;

- generation of new ideas.

These models are based on an orientation towards an intelligent workforce integrated into the production system; continuous enrichment of knowledge and professional development; flexible workforce - "participatory economy"; partnership relations between the participants in the process, which will determine the application of nonlinear development models in crisis situations.

Scientifically, it is necessary to revive humanistic morality, openness, trust, and spiritual collectivism to understand the personal responsibility to the generation.

Example. The managers of KZ Rostselmash LLC, as they realized the need for the principle of partnership in innovative activities with personnel, were forced to restructure their professional and ethical responsibility to implement an innovative strategy - the development of new models of harvesters, i.e., understanding the need to implement professional and moral standards - to comply with the code of ethical conduct in the team (Ovcharenko \& Larkina, 2019).

The globalization of a crisis economy predetermines the implementation of innovative transformations by the leaders, which are turning into a constant and dominant systemic economic process in the context of increasing the scope of application of innovative domestic technologies, as well as the implementation of an innovative strategy of external diversification - the creation of an innovative product-service.

Innovative competition determines the practical application of the methodology for the diffusion of innovative technologies in the implementation of the organization's innovative strategy, considering the crisis situation and the uncertainty of the market.

Subject to the above, it is appropriate to refer to the President of the Russian Federation V.V. Putin's proposals: "We need to make a serious inventory of development institutions. Their activities disintegrated into many disparate projects, sometimes not directly related to innovation. That's not what we made these development tools for. It is necessary to restore the strategic vector for a technological breakthrough in their work (Putin, 2013). Russia has hard-working and educated people with an innate will to win, be free and independent" (Abdurakhmanova et al., 2020).

The implementation of such methods determines the synergistic effect of the priority of the country's innovative development focus. A key factor in the effective introduction of innovative technologies is the ability of the managing leaders to implement an innovative strategy based on analytical tools:

- scientific and methodological substantiation of the effectiveness of technologies;

- assessment of the level of innovative potential;

- analysis of the innovative activity of personnel; 
- creation of new innovative management models;

- formation of an innovative culture of the organization;

- determination of the future innovative and technological development of the organization;

this will flexibly increase the scope of innovative activity of horizontal and vertical diversification and clearly define priorities, considering the impact of environmental factors, creating social equilibrium in the internal environment to understand future technological trends in the innovation sphere based on technological monitoring.

Analysis and assessment of theoretical methods and practical approaches determine the creation of a methodological basis for the effective use of innovative technologies in the innovative development of an organization, implemented by models of innovation activity considering their life cycle, understanding their essence in the formation of a new economy, in which the introduction of innovation several times increased labor productivity in all industries.

V.V. Putin noted that "we consider mechanical engineering as one of the drivers of the domestic economy. An industry with a huge export potential should and can become a symbol of national success, technological leadership of Russia - as, for example, our defense industry complex has done" (Putin, 2016).

The peculiarity of the current situation is that the global economic crisis determines not only survival but also integration with a mutually beneficial partnership of interaction between the state, science, education, production, and society based on the creation and implementation of innovative information and digital technologies while generating a stream of innovations that satisfy the constantly changing needs of society. That is, being a leader means running for life, as a new innovative environment is being formed, characterized by the following aspects:

- revolution in information and innovative technologies;

- arch-significance of intangible resources;

- generation of intellectual factors;

- instant diffusion of innovative knowledge and innovations.

Analysis and algorithm of the logic of the above allows us to assert that the success of the implementation of these factors is confirmed by the creation of a new paradigm of education not only for leadersinnovators able to carry out innovative activities in the organization, but also create innovative knowledge of personnel at all levels of the innovation cycle, manage them flexibly and effectively, involving hidden knowledge of all employees (Ovcharenko et al., 2018).

The transition to an innovative economy is characterized by the emergence of new multidimensional problems with a tendency of constant acceleration and growth. It determines the importance of new knowledge in the development of innovative social systems, which increases many times, leading to the creation of innovative methods of their management, especially in production, and contributes to the formation of an innovative climate in team, that is, the presence of a creative atmosphere in the interaction of all participants in this process, improving the research and production cycle.

Subject to the above, it is necessary to create innovative analytics based on information and digital technologies, which will make it possible to implement innovative and strategic planning that determines programs for innovative and social development for the future, considering the priority of the unique specifics of the regions. It is highly important to use mathematical forecasting to see interregional integration that reduces the socio-economic differences between territories, renewing old production facilities and creating new ones due to the need not only to keep young people in mini-cities but also to create new jobs (Ovcharenko \& Larkina, 2017). 
The authors note the need to create a concept of methodological aspects of the development model and forecast social and organizational systems using scientifically based forecasts for effective innovative and strategic planning due to the diversity and uncertainty of social processes in a global economic crisis.

As D. Bell notes, corporations are moving towards "sociologized production". Applying the approach of change based on organization modeling, they increase the strategic and innovative efficiency of achieving risk reduction, which determines the optimization of communications into a flexible interaction of all levels of management, applying innovative information technologies, which leads to direct participation in the process of creating new benefits for society and values in organizations - this fosters new opportunities for mutually beneficial creative partnerships with consumers, satisfying their future wishes.

Success in the innovative development of an organization is predetermined in the new conditions of its innovative activity by a constant increase in competence and intelligence and a key vector of increasing the competence of each employee and updating his knowledge and organizational skills of different-level managers.

P. Drucker noted in his "The Age of Discontinuity" that "At the present stage, the world society is in the era of the emergence of new sciences: biotechnology, bioengineering and molecular engineering (intramolecular control of atoms). These sciences are the phenomena of the creation of new forms of matter - the beginning of the fifth Kondratieff wave.

Studies of approaches to the application of innovative information technologies show that Russia has many ideas and innovations, which, however, are not in demand both by the state and by corporations due to their lack of innovative activity, which must be urgently forced, which will predetermine the creation of priority industries of innovative and specialized research centers, contributing to the creation of new innovative knowledge and the introduction of innovations, as well as the simultaneous operation of special economic zones in all regions and the modernization of their economies on the basis of a mutually beneficial partnership between the state, production with science and education with specific investment support from the state (Ovcharenko \& Larkina, 2017).

Example. We see such confirmation in the application of a behavioral approach in personnel management at KZ Rostselmash LLC, which allows each employee to implement their own creative capabilities since this approach is based on increasing the efficiency of human resources based on the creation of innovative traditions in team and culture, as well as a humane mission coordinated with the team.

Therefore, the extreme crisis situation in micro-and macro-economics should become an impulse for a macro-innovative breakthrough (Spartak, 2009).

In practice, the development and implementation of innovations cover all aspects of the organization's innovative activities, and the creation of effective organizational methods for managing innovations is based on the ability of the organization's leaders to create innovative open mindedness of personnel to innovative changes in its activities when using humane organizational structures and flexible methods for motivating participants in these processes.

L.N. Ogolev notes that "the dominant in the formation of the model of economic growth of the XXI century should be a system of innovative processes, scientific knowledge, new technologies, products and services, as well as cognitive innovations embodied in inventions, know-how and various material carriers" (Ogoleva, 2004). In support of this, P. Drucker noted in his research that an innovation introduced into production turns into an innovative result of innovative activity, which not only possesses economic feasibility and price but also has a social value in the form of social innovation - a change of a new type of thinking and lifestyle of each person. 
The logical conclusion of such aspects is the vision of prospects for development and the ability of leaders to apply innovative project management in creating innovations to meet the community's innovative needs subject to the time factor.

Economic globalization predetermines the future development of the neo-community through the creation of social and spiritual creativity - the self-expression of each individual - the creator of the life of the future based on the noospheric culture. Therefore, the most important is creating and implementing an innovative management paradigm of the XXI century based on civil society.

\section{CONCLUSION}

The content of the scientific, technical, and technological model of Russia in the XXI century will be largely determined by the participation of the state in its formation with the increasing requirements for humanistic culture in innovative production management and the need for humanitarian education among managers - an alternative to self-manifestation of creativity in innovative management of organizations.

Such an innovative approach determines the implementation of the strategy of innovative changes based on the moral and psychological protective mechanism of collective origin; that is, the creation of moral immunity in the team is the personal spirituality in the creative activity of the innovative organization. Young workers are the first who need this, and the task of managers is not to miss the time of their moral formation, which will contribute to the creative development of the NEO-society.

The organization, like never before, must be managed by innovative managing leaders being able to create only innovative educational product-services based on:

- creation of neo-innovative knowledge in teams;

- the ability for time-management;

- creation of an innovative image;

- the ability to create a neo-team with intention;

- insight - innovative thinking;

- the ability to create new customers;

- key competencies to be able to manage personnel knowledge;

- investment valence of the organization;

- innovative marketing foresight.

The economy is now changing from a social type to a scientific and innovative phase. On the one hand, it is necessary to develop an innovative policy, mission, values, and traditions of employees, and on the other hand, in the modern global crisis, an innovative management theory is developing, contributing to the transition to the management of constant innovative changes with an understanding of the new business philosophy in the context of its realization.

\section{REFERENCES}

Abdurakhmanova, G., Shayusupova, N., Irmatova, A., \& Rustamov, D. (2020). The role of the digital economy in the development of the human capital market. Архив научных исследований, (25).

Anchishkin, A.I. (2003). Forecasting the rates and factors of economic growth. - M.: "MAKS Press" LLC, $300 \mathrm{p}$.

Berdiaev, N.A. (1990). Collected works. V. 4. Spiritual foundations of the Russian revolution (Articles 1917-1918). Philosophy of Inequality. - Paris: YMCA-Press, 598 p. 
Berdiaev, N.A. (2010). The fate of Russia. - M.: AST, Astrel, Poligrafizdat, 334 p.

Iakovets, Iu.V. et al. (2000). Innovation theory, mechanism, government regulation: a textbook. - M.: RANEPA, $237 \mathrm{p}$.

Jack, L. S. (1977). The Soviet Strategic Culture: Implications for Limited Nuclear Operations, Santa Monica, CA, Rand R-2154-AF, 40 p.

Ogoleva, L.N. (2004). Innovation management: a textbook. - M.: INFRA-M, - 238 p.

Ovcharenko, A.N. (2007). Strategic management in political activity: theoretical and methodological foundations. The State Commission for Academic Degrees and Titles topic of the dissertation and the abstract - 23.00.02, Ph.D. Politics. - M. 329 p.

Ovcharenko, G.V., \& Larkina, N.G. (2017). The value aspect of innovation. Monograph. - YURIU RANEPA Publishing House, 142 p.

Ovcharenko, G.V., Larkina, N.G. (2019). Innovative management. Textbook / YuRIU RANEPA, RostovOn-Don, 333 p.

Ovcharenko, G.V., Larkina, N.G., \& Korsunov, D.A. (2020). Institutional imperatives of innovative development of technological-socioecological systems. Monograph. - YURIU RANEPA Publishing House, $124 \mathrm{p}$.

Ovcharenko, G.V., Larkina, N.G., Ovakimian, M.A., \& Melikhova, B.S. (2018). Innovative knowledge as a key vector in the development of a modern organization. Monograph. - Publishing house YuRIU RANEPA, $126 \mathrm{p}$.

Pestel, P.I. (1972). Russian truth. Anthology of world philosophy (in 4 volumes). V. 4. - M.: Mysl, 711 p.

Plato. (2015). The State. Translated by A.N. Egunov - M.: Academic project, 398 p.

Putin, V.V. (2008). On the development strategy of Russia until 2020. Speech at an expanded meeting of the State Council. February 8. http://www.kremlin.ru/events/president/transcripts/24825

Putin, V.V. (2012). We need a new economy. Vedomosti. No.3029 of 30.01.

Putin, V.V. (2013). Address to the Federal Assembly on December 12, www.kremlin.ru

Putin, V.V. (2014). Speech at the St. Petersburg International Forum of 23.05.2014.

Putin, V.V. (2016). Speech at the Congress of the Union of Mechanical Engineers of Russia on 19.04.

Semenov, E.E. (2013). Virtual network paradigm of political activity. Power, 4, 34-38.

Spartak, A.N. (2009). Towards a new paradigm of economic growth. BIKI, 65, 1-7. 